\title{
Apigenin Inhibits Human SW620 Cell Growth by Targeting Polyamine Catabolism
}

\author{
Jing Wang, ${ }^{1}$ TongMing Li, ${ }^{1}$ Linquan Zang, ${ }^{2}$ Xuediao Pan, \\ Sujun Wang, ${ }^{2}$ Yanyan $\mathrm{Wu},{ }^{2}$ and Guixiang Wang ${ }^{2}$ \\ ${ }^{1}$ School of Chinese Herbology, Guangzhou University of Chinese Medicine, Guangdong Province, Guangzhou, China \\ ${ }^{2}$ School of Pharmacy, Guangdong Pharmaceutical University, Guangdong Province, Guangzhou, China \\ Correspondence should be addressed to Guixiang Wang; wangguixiang306@126.com
}

Received 26 January 2017; Revised 5 April 2017; Accepted 12 April 2017; Published 10 May 2017

Academic Editor: Kuzhuvelil B. Harikumar

Copyright (C) 2017 Jing Wang et al. This is an open access article distributed under the Creative Commons Attribution License, which permits unrestricted use, distribution, and reproduction in any medium, provided the original work is properly cited.

Apigenin is a nonmutagenic flavonoid that has antitumor properties. Polyamines are ubiquitous cellular polycations, which play an important role in the proliferation and differentiation of cancer cells. Highly regulated pathways control the biosynthesis and degradation of polyamines. Ornithine decarboxylase (ODC) is the rate-limiting enzyme in the metabolism, and spermidine/spermineN1-Acetyl transferase (SSAT) is the rate-limiting enzyme in the catabolism of polyamines. In the current study, the effect of increasing concentrations of apigenin on polyamine levels, ODC and SSAT protein expression, mRNA expression, cell proliferation and apoptosis, and the production of reactive oxygen species (ROS) was investigated in SW620 colon cancer cells. The results showed that apigenin significantly reduced cell proliferation, decreased the levels of spermidine and spermine, and increased previously downregulated putrescine contents. Apigenin also enhanced SSAT protein and mRNA levels and the production of reactive oxygen species in SW620 cells, though it had no significant effect on the levels of ODC protein or mRNA. Apigenin appears to decrease the proliferation rate of human SW620 cells by facilitating SSAT expression to induce polyamine catabolism and increasing ROS levels to induce cell apoptosis.

\section{Introduction}

Apigenin, a flavonoid commonly present in many edible fruits, vegetables, and Chinese herbs, is known to possess antitumor properties and thus has therapeutic potential for the treatment of cancer. A growing body of evidence suggests that apigenin exhibit antitumoral effects by retarding growth and inducing apoptosis through activation of pentose phosphate pathway-mediated NADPH generation in HepG2 human hepatoma cells [1]; induction of apoptosis via the PI3K/AKT and ERK1/2 MAPK pathways [2, 3]; decreasing the viability, adhesion, and migration of cancer cells $[4,5]$; and modulating angiogenesis and metastasis [6]. Colorectal cancer (CRC) is the third most common cancer among men and the second most common among women worldwide. There are few treatment options for colon cancer; thus, preventative therapeutic approaches for this malignancy are necessary.

Data suggest that apigenin inhibits the proliferation of a wide range of cancer cells, including colorectal carcinoma cells, by inducing apoptosis [7]. Nevertheless, little is known about apigenin's interruption of certain cellular processes and whether this is involved in cancer inhibition.

Putrescine (Put), spermidine (Spd), and spermine (Spm) are polyamines. Polycationic polyamines are essential factors in mammalian development, and in eukaryotic cell differentiation and proliferation [8-12]. The concentration of cellular polyamines is typically low and is precisely controlled by metabolic modulation including polyamine uptake, transport, and interchange [8]; thus the intracellular concentration of polyamines is generally in the millimolar range. Polyamine metabolism (summarized in Figure 1) is strictly regulated 


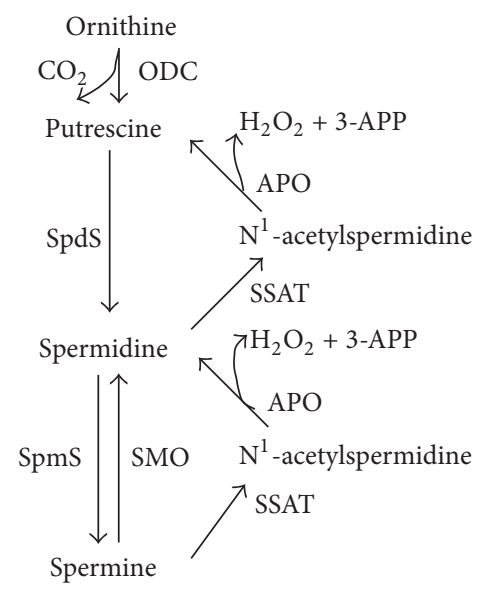

Figure 1: Polyamine metabolism. Ornithine decarboxylase (ODC) is required for the first step of polyamine synthesis in which ornithine is decarboxylated to produce putrescine. In turn, putrescine is converted sequentially to spermidine and spermine by the action of adenosylmethionine decarboxylase and spermidine and spermine synthases, respectively. The conversion to lower level polyamines is made in either two steps, by the spermidine/spermine $\mathrm{N}^{1}$-acetyltransferase (SSAT)/ $\mathrm{N}^{1}$-acetylpolyamine oxidase (APAO) mechanism, or directly from spermine to spermidine by spermine oxidase (SMO). The activities of both APAO and SMO lead to the production of $\mathrm{H}_{2} \mathrm{O}_{2}$ and aldehydes 3-acetoaminopropanal (3-AAP) and 3-aminopropanal (3-AP).

under certain physiological conditions [13-15]. Ornithine decarboxylase (ODC), the rate-limiting enzyme of polyamine biosynthesis, plays an important role in polyamine generation, whereas spermidine/spermine $\mathrm{N}^{1}$-acetyltransferase (SSAT) is the rate-limiting enzyme of catabolism (Figure 1). Polyamines play vital roles in cell proliferation through association with nucleic acids, maintenance of chromatin conformation, regulation of specific gene expression, regulation of ion-channels, maintenance of membrane stability, and scavenging of free-radicals (especially spermidine) [1621]. Previous research has demonstrated the mitogenic role of polyamines in enterochromaffin-like cells in health and disease [22]. Interestingly, high levels of polyamines are found in several types of tumors and play a unique role in cancer cell proliferation and survival [23]. The biological relationship between increased polyamine quantification and neoplasm growth has been well established. Specifically, hyperproliferative tumor cells have been shown to be accompanied by abnormally high polyamine levels [24-26]. Interest in the role of polyamines in hyperproliferative and cancerous tissues has led to the development of specific inhibitors for every step of polyamine metabolism, which has led to the development of several chemotherapeutic drugs. For example, treatment with the ornithine decarboxylase (ODC) inhibitor alpha-difluoromethylornithine (DFMO) results in the depletion of polyamines and inhibition of DNA synthesis, which consequently exerts a delay in cell cycle approaches [27-30]. Unfortunately, in most cancer cell lines, treatment with DFMO has a cytostatic rather than a cytotoxic effect [31-35]. In vitro studies consistently show that DFMO causes large increases in transmembrane polyamine uptake [36,37].

Polyamine catabolic pathways of polyamines occur via a one-step process, directly from spermine to spermidine by spermine oxidase (SMO) or a two-step process via spermidine/spermine $\mathrm{N}^{1}$-acetyltransferase $(\mathrm{SSAT}) / \mathrm{N}^{1}$ acetylpolyamine oxidase (APAO). Acetylated polyamines have two potential advantages: acetylated polyamine can be exported from the cell and acetylated spermidine and spermine are substrates for FAD-dependent, peroxisomal APAO. Spermidine or putrescine is the product of APAO, depending on the starting substrate, 3-acetoaminopropanal (3-AAP) or $\mathrm{H}_{2} \mathrm{O}_{2}$, respectively [38] (Figure 1). SSAT is an inducible enzyme, while APAO is generally constitutively expressed and rate-limited by the availability of the acetylated substrate. The coupled responses of SSAT and APAO, in particular, are responsible for preventing the overaccumulation of polyamines $[39,40]$. It is worth noting that $\mathrm{H}_{2} \mathrm{O}_{2}$ is a by-product of the polyamine catabolic reaction, which is catalyzed by acetylpolyamine oxidase (APAO). It has been well established that $\mathrm{H}_{2} \mathrm{O}_{2}$, produced via APAO activity, is responsible for apoptosis [41]. Therefore, increases in SSAT expression produce increased acetylpolyamine derivatives, which are the preferred substrates for APAO. Furthermore, oxidation of these acetyl-polyamines by APAO produces $\mathrm{H}_{2} \mathrm{O}_{2}$, which then induces SSAT expression. Thus, the activities of APAO and SSAT activate the system that generates cellular death $[16,42]$. This cycle of excessive acetylation and oxidation amplifies oxidative stress in the cell, thus producing a high local concentration of $\mathrm{H}_{2} \mathrm{O}_{2}$, possibly high enough to induce programmed cell death. $\mathrm{ROS}\left(\mathrm{H}_{2} \mathrm{O}_{2}\right.$ is typically one) at low levels refer to different signaling pathways. For example, activation of the NF-kB, ERK1/2, and PI3K pathways is regulated by low ROS levels and leads to an increase in cell growth and proliferation. By contrast, ROS at high levels may disrupt proper signaling pathways in the cell causing damage to DNA and other crucial macromolecules, which, in turn, may lead to DNA instability and consequently, senescence, or apoptosis [43, 44] (Figure 2). 


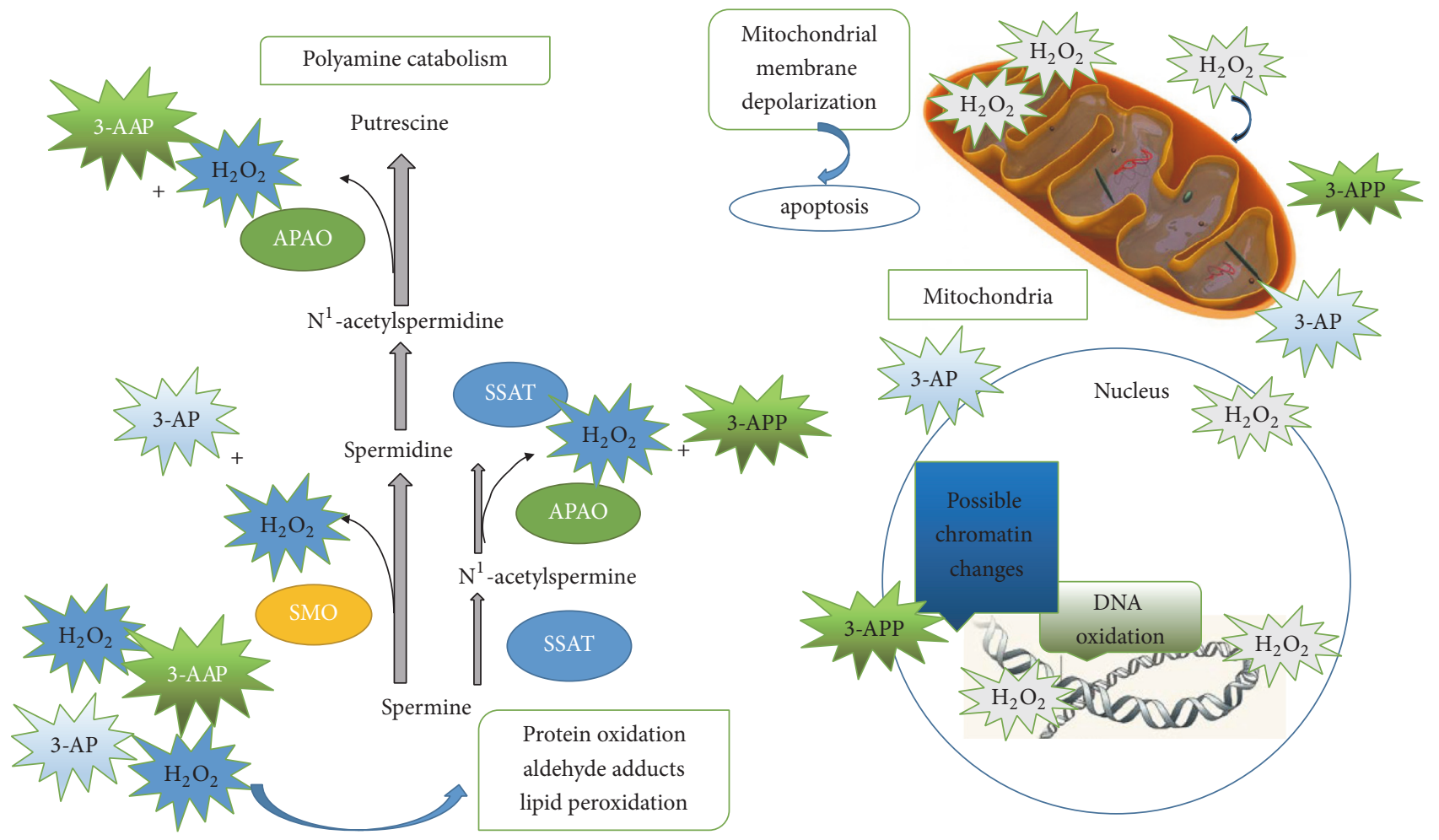

FIGURE 2: Potential contributions of polyamine catabolism to cell damage. Spermine is catabolized by spermine oxidase (SMO) to produce spermidine, 3-aminopropanal (3-AP), and $\mathrm{H}_{2} \mathrm{O}_{2}$. Spermine and spermidine can both be catabolized by spermidine/spermine $\mathrm{N}^{1}$ acetyltransferase (SSAT) to produce $\mathrm{N}^{1}$-acetylspermine and $\mathrm{N}^{1}$-acetylspermidine, which can then serve as substrates for $\mathrm{N}^{1}$-acetylpolyamine oxidase (APAO). This produces either spermidine or putrescine, respectively, along with 3-acetoaminopropanal (3-AAP) and $\mathrm{H}_{2} \mathrm{O}_{2}$. These reactive aldehydes and $\mathrm{H}_{2} \mathrm{O}_{2}$ are capable of damaging cellular machinery, lipids, and DNA, leading to cellular dysfunction or apoptosis.

The aim of this study was to determine the functional role of SSAT and polyamine catabolism in apigenin-treated colon cancer cells and to elucidate whether apigenin-induced polyamine catabolism, caused by an increase in SSAT activity, induced apoptosis via an increase in ROS production. The combination of polyamine biosynthesis and catabolism inhibition, via apigenin, may be a promising new therapeutic option for colon cancer and should be further studied in clinical trials in the future.

\section{Materials and Methods}

2.1. Chemicals, Reagents, and Antibodies. CCK-8 kit (Yeasen), antibodies against anti-ODC, SSAT (NOVUS), $\beta$-actin (boster), secondary anti-mouse, anti-rabbit (Boster) DCFH-DA (Beyotime), Annexin V-FITC (KeyGEN BioTECH), Enhanced chemiluminescence (Thermo), Dulbecco modified Eagle medium (Gibco), foetal bovine serum (Gibco), Tyrisin (Gibco), PrimeScript ${ }^{T M}$ RT reagent kit with gDNA Eraser (Takara), SYBR ${ }^{\circledR}$ Premix Ex Taq $^{T M}$ II (TaKaRa), Apigenin (Aladdin), DFMO (Sigma), and SPD (Sigma) were obtained.

2.2. Cell Culture Conditions. Human colon SW620 cells were obtained from the Institute of Biochemistry and Cell Biology,
CAS (Shanghai, China). Cells were routinely cultured in Dulbecco modified Eagle medium (DMEM) supplemented with $10 \%$ foetal bovine serum (FBS) and equilibrated with humidified $5 \% \mathrm{CO}_{2}$ in air at $37^{\circ} \mathrm{C}$. Cells in the exponential phase of growth were used in experiments.

2.3. Proliferation Assay of SW620 Cells. 2-(2-Methoxy-4-nitrophenyl)-3-(4-nitrophenyl)-5-(2,4-disulfophenyl)-2H-tetrazolium Sodium Salt (CCK-8) was used to measure SW620 cells proliferation. Cells were seeded onto 96-well tissue culture plates $\left(5 \times 10^{3}\right.$ cells per well) in Dulbecco modified Eagle medium with 10\% FBS. Cells were cultured in serumfree Dulbecco modified Eagle medium for 24 hours, and different concentrations of apigenin $(10 \mu \mathrm{M}, 20 \mu \mathrm{M}, 40 \mu \mathrm{M}$, and $80 \mu \mathrm{M})$ and DFMO $(2.5 \mathrm{mM})$ were then added. After 24, 48, and 72 hours of incubation, the cells were treated with $10 \mu \mathrm{l}$ WST- 8 per well for 4 hours at $37^{\circ} \mathrm{C}$ in humidified $\mathrm{CO}_{2}$. WST-8 conversion to formazan by metabolically viable cells was monitored using a spectrophotometer at an optical density of $450 \mathrm{~nm}$.

2.4. Polyamine Analysis. To determine cellular polyamine content, $1 \times 10^{6}$ cells were seeded on $60 \mathrm{~mm}$ Petri dishes and allowed to attach overnight. Cells were then treated with 
TABLE 1: Amplification primer sequences used.

\begin{tabular}{ll}
\hline Gene & Primer \\
\hline \multirow{2}{*}{ ODC } & Forward: $5^{\prime}$-GGGCTGGGTTGGTTTCA-3 \\
& Reverse: $5^{\prime}$-ACGCTGGGTTGATTACGC-3' \\
SSAT & Forward: $5^{\prime}$-CAGTGACATACTGCGGCTGA-3' \\
& Reverse: $5^{\prime}$-GTGCTCTTTCGGCACTTCTG-3' \\
GAPDH & Forward: 5'-AACGGATTTGGTCGTATTGGG-3' \\
& Reverse: $5^{\prime}$-CCTGGAAGATGGTGATGGGAT-3' \\
\hline
\end{tabular}

DFMO $(2.5 \mathrm{mM})$, SPD $(0.5 \mu \mathrm{M})$, apigenin $(10 \mu \mathrm{M}, 20 \mu \mathrm{M}$, and $40 \mu \mathrm{M})$, or apigenin $(10 \mu \mathrm{M}, 20 \mu \mathrm{M}$, and $40 \mu \mathrm{M})$ in combination with DFMO $(2.5 \mathrm{mM})$.

Cells were harvested after $48 \mathrm{~h}$ treatment and $1 \mathrm{ml}$ of trichloroacetic acid (5\%) was added to each sample to precipitate the protein. Samples were immediately run on HPLC (Shimadzu) after benzoylation processing to determine benzoyl-polyamine derivatives. Polyamine levels are expressed as concentration values in $\mathrm{nmol} / \mathrm{mg}$ of protein.

2.5. Western Blot Analysis. Expression levels of proteins involved in polyamine metabolism (ODC, SSAT) were analyzed by Western blot and normalized to the mean expression of $\beta$-actin as described in a previous study.

SW620 cells were cultured with $10 \mu \mathrm{M}, 20 \mu \mathrm{M}$, or $40 \mu \mathrm{M}$ of apigenin and DFMO $(2.5 \mathrm{mM})$. After $48 \mathrm{~h}$ treatment, the cells were washed twice in ice-cold 1x PBS and resuspended in a buffer consisting of $20 \mathrm{mM}$ Tris- $\mathrm{HCl}$ ( $\mathrm{pH} 7.4$ ), $150 \mathrm{mM} \mathrm{NaCl}, 1 \mathrm{mM}$ EDTA (pH 8.0), 1\% Triton X-100, and $0.1 \%$ SDS, supplemented with complete protease inhibitor cocktail (Beyotime). The lysates were then centrifuged at $12000 \mathrm{rpm}$ for 25 minutes at $4^{\circ} \mathrm{C}$. The supernatant was used for protein estimation using a BCA protein assay kit (Thermo). Approximately, 40-60 $\mu \mathrm{g}$ of protein was loaded into each well of SDS-gel (10\% or $12 \%)$ and transferred onto a PVDF (minipall) membrane. The blots were then blocked in 5\% milk in TBST (Tris buffered saline-tween 20) for $1 \mathrm{~h}$ and incubated overnight at $4^{\circ} \mathrm{C}$ with the relevant primary antibodies $(1: 1000)$ diluted in $5 \%$ milk in TBST. Following this, HRP-conjugated secondary antibodies (1:5000), diluted in $5 \%$ milk/TBST, were added and incubated for 1 hour, washed with $1 \mathrm{x}$ TBST and developed using ECL detection reagent (Thermo). For sequential antibody reprobing, blots were stripped using $1 \mathrm{x}$ TBST. Band densities were measured using image $\mathrm{J}$ software and results were normalized to corresponding loading controls.

2.6. Real-Time Reverse Transcription-PCR Analysis. The total RNA of the cells was isolated using RNAiso Plus, following the manufacturer's protocol. First-strand cDNA was synthesized with a PrimeScript II 1st Strand cDNA Synthesis Kit, using $3 \mu \mathrm{l}$ of total RNA and 10 pmol of primers, according to the manufacturer's instructions (Table 1). Real-time PCR was performed with SYBR Premix Ex Taq II, following the manufacturer's protocol. Gene expression levels were normalized to those of GAPDH.
2.7. Determination of Generation of Reactive Oxygen Species. The intracellular formation of reactive oxygen species (ROS) was measured using $7^{\prime}$-dichlorodihydrofluorescin diacetate (DCFH-DA) (Beyotime). The nonfluorescent compound, DCFH-DA, penetrates into the cell and is cleaved by intracellular esterases, resulting in the formation of $2^{\prime}, 7^{\prime}$ dichlorodihydrofluorescin (DCFH), the oxidation of which (due to oxidative stress) generates the fluorescent compound dichlorofluorescein. Thus, DCF fluorescence represents the rate and quantity of ROS produced. After the Api treatment procedure, cells were stained with $1 \mu \mathrm{M}$ DCFH-DA at $37^{\circ} \mathrm{C}$ for $30 \mathrm{~min}$ and washed twice with PBS and the fluorescence was measured using an FCM (BD Bioscience).

2.8. Apoptotic Assay. The Annexin V-FITC Apoptosis Detection (KeyGEN) was used to assess cell apoptosis induced by apigenin treatment. SW620 cells were cultured in $60 \mathrm{~mm}$ Petri dishes and allowed to grow overnight. The cells were then treated with AP $(10 \mu \mathrm{M}, 20 \mu \mathrm{M}$, and $40 \mu \mathrm{M})$, DFMO $(2.5 \mathrm{mM})$, or DFMO $(2.5 \mathrm{mM})$ in combination with AP $(40 \mu \mathrm{M})$. After $48 \mathrm{~h}$ of treatment, cells were harvested and washed twice with PBS, resuspended with $500 \mu \mathrm{l}$ binding buffer, and stained with $5 \mu \mathrm{l}$ Annexin V-FITC and $5 \mu \mathrm{l}$ PI for $15 \mathrm{~min}$ at the room temperature in the dark. Cells were analyzed by FCM (BD).

2.9. Statistical Analysis. All data was statistically analyzed by two-tailed unpaired Student's $t$-test and two-way ANOVA using GraphPad Prism version 5.04 for Windows, Graph Pad Software (La Jolla, California, USA). Error bars in the graphs were generated using \pm standard deviation $(\mathrm{SD})$ values. A probability of $p<0.05$ was considered significant for all statistical analysis.

\section{Results}

3.1. Effect of Different Concentrations of Apigenin on the Growth of SW620 Cells. To determine the effect of increasing concentrations of apigenin and DFMO on SW620 cell proliferation, cell viability was measured using 2-(2-Methoxy-4nitrophenyl)-3-(4-nitrophenyl)-5-(2,4-disulfophenyl)-2H-tetrazolium Sodium Salt (CCK-8). SW620 cells were treated for 24,48 , or 72 hours with apigenin concentrations ranging from $10 \mu \mathrm{M}$ to $80 \mu \mathrm{M}$, and DFMO $(2.5 \mathrm{mM})$ was used as a positive control (Figure 3(a)). After 48 and 72 hours, apigenin significantly reduced the cell proliferation compared to untreated control cells, while DFMO caused a slight reduction in cell viability compared to apigenin, indicating that apigenin is more selective than traditional chemotherapeutic compounds (Figure 3(c)). The $\mathrm{IC}_{50}$ of apigenin was $88.3 \pm 12.3 \mu \mathrm{M}$ at 24 hours, $54.9 \pm 8.1 \mu \mathrm{M}$ at 48 hours, and $30.6 \pm 6.1 \mu \mathrm{M}$ at 72 hours (Figure $3(\mathrm{~b})$ ). As is evident, 72 hours was the most effective of the three periods of time.

3.2. Modulation of ODC and SSAT Protein Expression by Apigenin and DFMO. Western blot analysis (Figure 4) was used to show that ODC protein levels were not affected by apigenin $(10,20$, and $40 \mu \mathrm{M})$, while DFMO $(2.5 \mathrm{mM})$ 


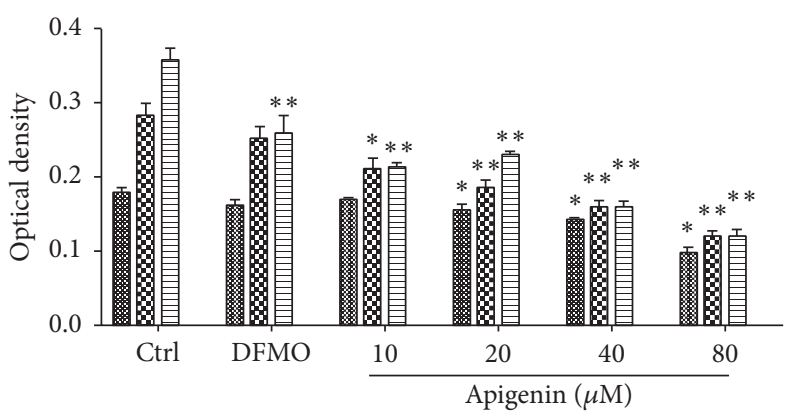

ED 24

픈 48

72

(a)

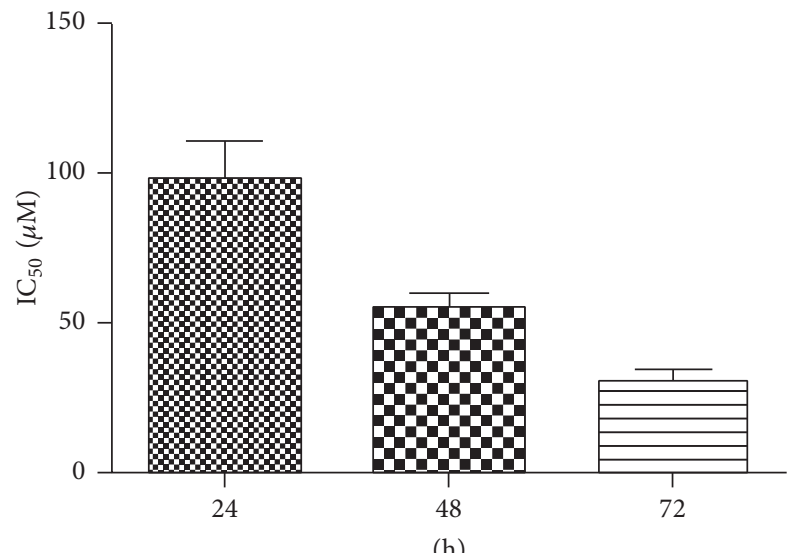

(h)

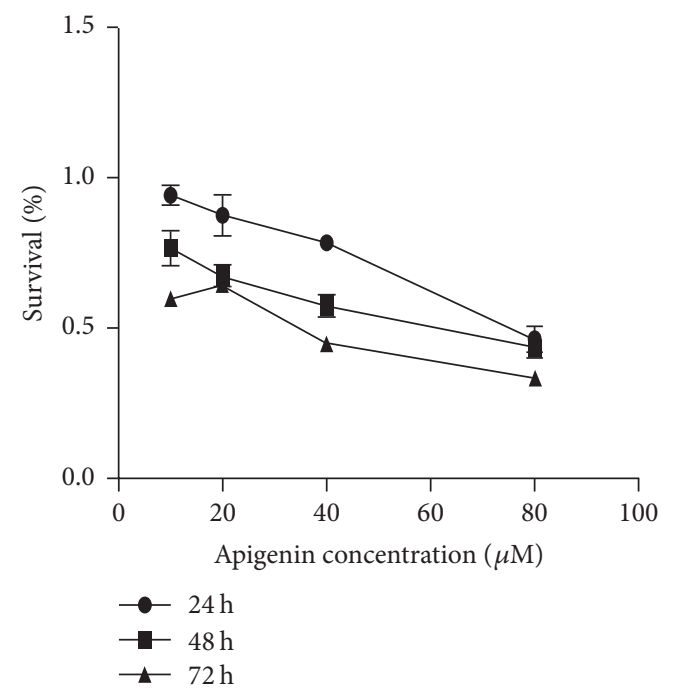

(c)

FIGURE 3: (a) Effect of increasing concentrations of apigenin and DFMO (2.5 mM) on the conversion of CCK8 Sodium Salt in SW620 cells. (c) The dose-response curve of apigenin and (b) the comparison of the $\mathrm{IC}_{50}$ values $(\mu \mathrm{M})$ for apigenin in SW620 cells were determined after $24-, 48-$, and 72 -hour exposure to the drugs. The $\mathrm{IC}_{50}$ is defined as the concentration causing $50 \%$ growth inhibition in treated cells compared to controls. All data represent the results of 6 different experiments (mean value $\pm \mathrm{SD}$ ). The $p$ value was determined by one-way analysis with Dunnett's posttest. ${ }^{*} p<0.05$ and ${ }^{* *} p<0.01$ versus control.

significantly reduced the ODC protein levels in SW620 cells. These results indicate that ODC may not be the target of apigenin. It is interesting to note that SSAT protein levels were upregulated with apigenin treatment (Figures 3(a) and 3(b)).

3.3. Apigenin Treatment Affects SSAT mRNA Expression in $S W 620$ Cells. In order to validate the mechanism by which apigenin affects ODC and SSAT, ODC and SSAT mRNA levels were studied after treatment with apigenin $(10,20$, and $40 \mu \mathrm{M})$, DFMO $(2.5 \mathrm{mM})$, and exogenous-spermidine $(5 \mu \mathrm{M})$ for $48 \mathrm{~h}$. Real-Time PCR analysis (Figure 5) demonstrated a significant increase in SSAT mRNA expression in response to apigenin treatment, while there were no significant changes in ODC mRNA levels after treatment with apigenin. Interestingly, exogenous-spermidine increased SSAT mRNA levels and decreased ODC mRNA levels, indicating that polyamine metabolism is homeostatic. This homeostasis was possibly disrupted by apigenin through promotion of polyamine catabolism by targeting SSAT.

3.4. Treatment with Apigenin Resulted in Acceleration of Cellular Polyamine Catabolism and Treatment with DFMO and Apigenin Combined Resulted in Depletion of Cellular Polyamine Levels. Further research was done to investigate cellular polyamine content after 48 hours of treatment with apigenin $(10,20$, and $40 \mu \mathrm{M})$, DFMO $(2.5 \mathrm{mM})$, and combination of DFMO and apigenin $(10,20$, and $40 \mu \mathrm{M})$.

Treatment with apigenin, DFMO, and a combination of apigenin DFMO a decreased specific intracellular polyamines, while polyamine contents were greatly increased by treatment with exogenous-spermidine (SPD) (Table 2 and Figure 6(a)). It is interesting to note that DFMO 


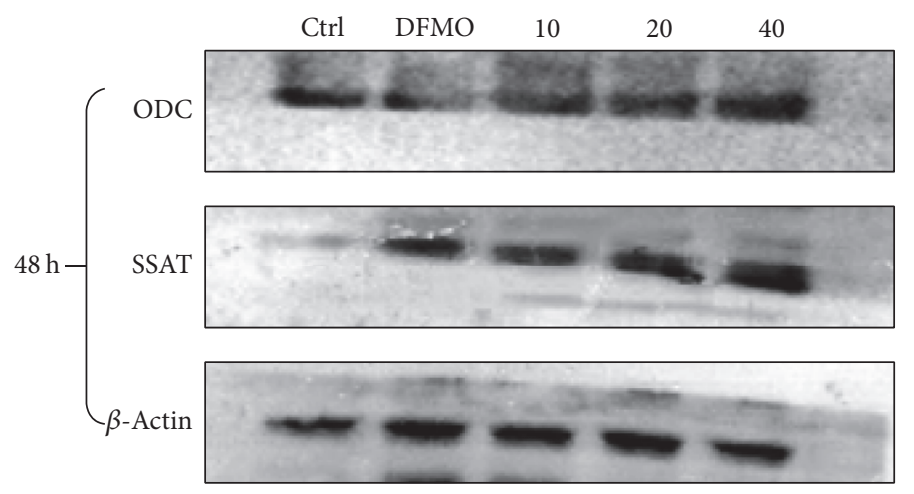

(a)
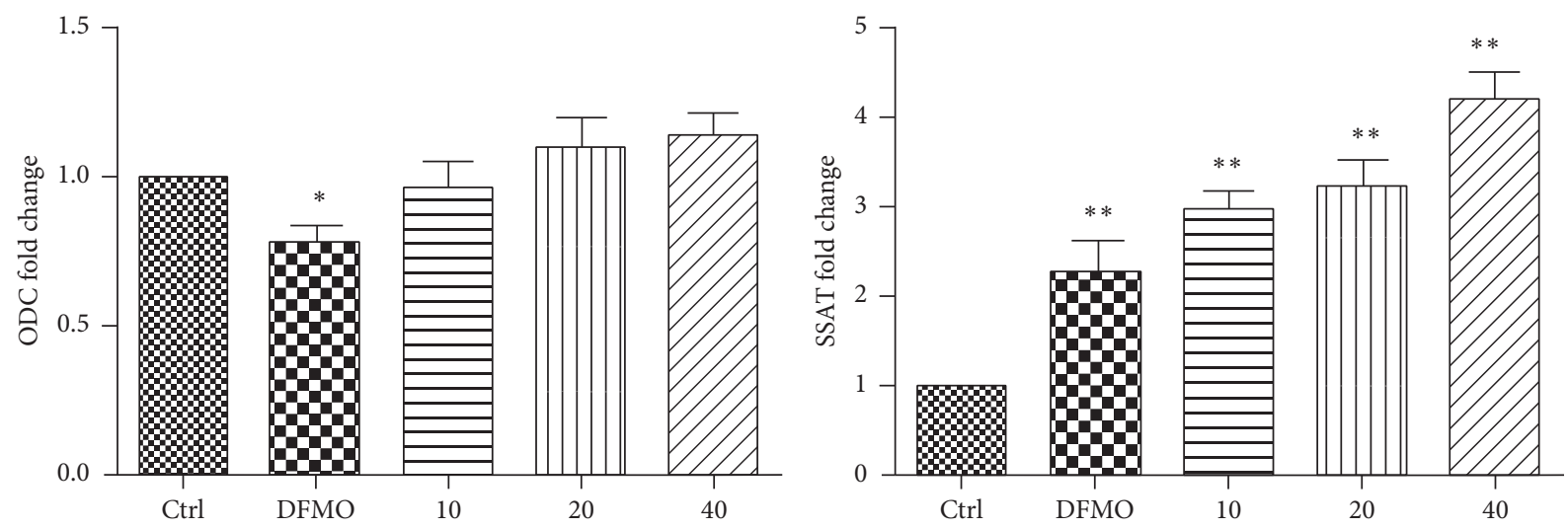

(b)

FIGURE 4: Western blot analysis and quantification. (a) Western blot analysis of ODC and SSAT protein levels in cells treated with apigenin (10, 20 , and $40 \mu \mathrm{M})$ and DFMO $(2.5 \mathrm{mM})$ for 48 hours. Twenty-five micrograms of total protein was loaded per lane. SSAT activity was observed at $48 \mathrm{~h}$. There was no significant activation of ODC after apigenin treatment at either concentration. (b) Quantification of ODC and SSAT expression in SW620 cells treated with apigenin $(10,20$, and $40 \mu \mathrm{M})$ and DFMO $(2.5 \mathrm{mM})$ at $48 \mathrm{~h} .{ }^{*} p<0.05$ and ${ }^{* *} p<0.01$ relative to untreated cells.

TABLE 2: Polyamine content (nmol/mg protein) of SW620 cells after exposure to different concentrations of apigenin (10, 20, and 40 $\mu \mathrm{M})$, DFMO $(2.5 \mathrm{mM})$, and a combination of DFMO and apigenin for $48 \mathrm{~h}$. The effect of exogenous-spermidine $(5 \mu \mathrm{M})$ after $48 \mathrm{~h}$ of treatment is also shown. The $p$ value was determined by one-way analysis with Dunnett's posttest. ${ }^{*} p<0.05$ and ${ }^{* *} p<0.01$ versus control.

\begin{tabular}{|c|c|c|c|c|}
\hline \multirow{2}{*}{ Treatment } & \multicolumn{4}{|c|}{ Growth parameter (nmol/mg protein) } \\
\hline & Putrescine & Spermidine & Spermine & Total polyamines \\
\hline Ctrl & $3.01 \pm 0.05$ & $12.53 \pm 0.02$ & $18.15 \pm 0.07$ & $33.69 \pm 0.02$ \\
\hline DFMO & $1.66 \pm 0.12^{* *}$ & $8.12 \pm 0.82^{*}$ & $13.78 \pm 0.29^{* *}$ & $23.55 \pm 0.97^{* *}$ \\
\hline SPD & $7.06 \pm 0.23^{* *}$ & $28.37 \pm 0.65^{* *}$ & $24.88 \pm 0.41^{* *}$ & $60.37 \pm 1.17^{* *}$ \\
\hline $10 \mu \mathrm{M}$ Api & $4.44 \pm 0.46^{*}$ & $13.07 \pm 0.52$ & $12.64 \pm 0.56^{* *}$ & $30.15 \pm 0.96^{* *}$ \\
\hline $20 \mu \mathrm{M}$ Api & $5.81 \pm 0.44^{*}$ & $11.53 \pm 0.42$ & $9.77 \pm 0.36^{* *}$ & $27.12 \pm 0.58^{* *}$ \\
\hline $40 \mu \mathrm{M}$ Api & $7.52 \pm 0.27^{* *}$ & $6.39 \pm 0.43^{* *}$ & $7.04 \pm 0.03^{* *}$ & $20.86 \pm 0.26^{* *}$ \\
\hline $\mathrm{DFMO}+10 \mu \mathrm{M}$ Api & $3.40 \pm 0.28$ & $8.47 \pm 0.60^{*}$ & $11.53 \pm 0.42^{* *}$ & $23.40 \pm 1.14^{* *}$ \\
\hline $\mathrm{DFMO}+20 \mu \mathrm{M}$ Api & $2.66 \pm 0.18^{*}$ & $6.39 \pm 0.44^{* *}$ & $7.39 \pm 0.61^{* *}$ & $16.44 \pm 0.88^{* *}$ \\
\hline $\mathrm{DFMO}+40 \mu \mathrm{M}$ Api & $1.46 \pm 0.17^{* *}$ & $4.31 \pm 0.21^{* *}$ & $5.50 \pm 0.33^{* *}$ & $11.27 \pm 0.50^{* *}$ \\
\hline
\end{tabular}



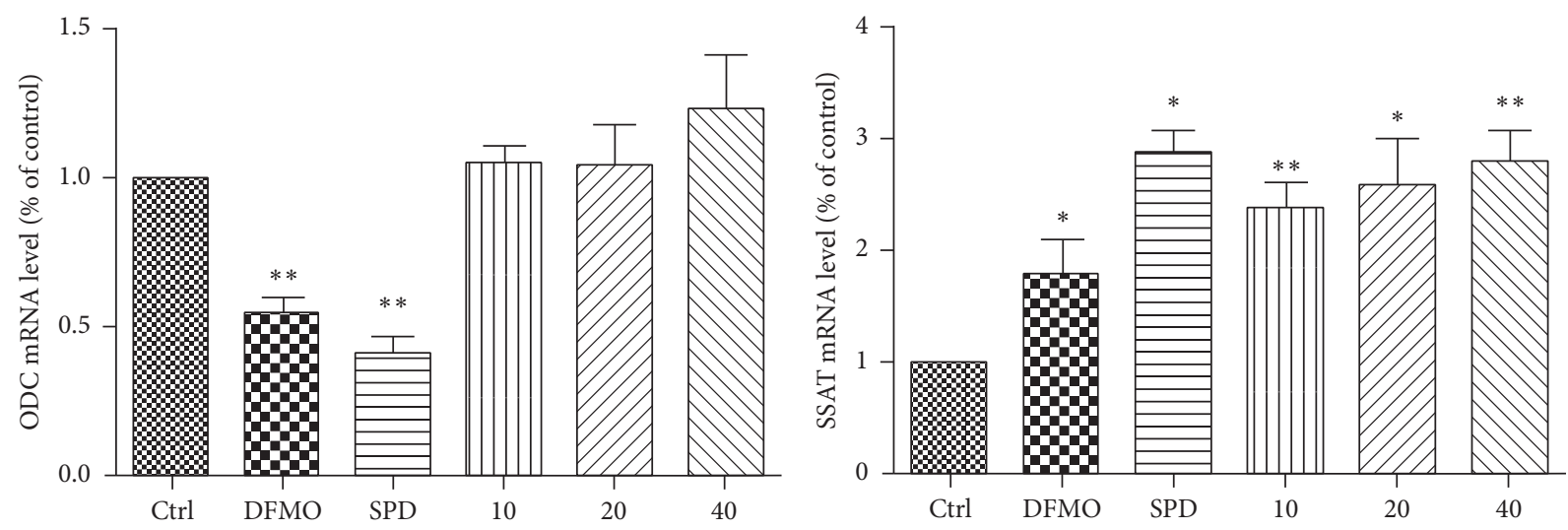

FIGURE 5: RT-qPCR analysis of ODC and SSAT mRNA expression in SW620 after $48 \mathrm{~h}$ of treatment with apigenin (10, 20, and $40 \mu \mathrm{M})$, DFMO $(2.5 \mathrm{mM})$, and exogenous-spermidine $(5 \mu \mathrm{M})$. RT-qPCR data are presented as fold change compared to untreated. The $p$ value was determined by one-way analysis with Dunnett's posttest. ${ }^{*} p<0.05$ and ${ }^{* *} p<0.01$ relative to untreated cells.

treatment alone almost completely depleted putrescine levels and significantly decreased the levels of spermidine and spermine in SW620 cells, while apigenin treatment resulted in a concentration-dependent increase in putrescine levels and decrease in spermine levels with a decrease in the level of total polyamine content (Figures 6(a) and 6(b)), indicating that polyamine catabolism is promoted by apigenin to some extent. Furthermore, combined treatment with DFMO and increasing concentrations of apigenin resulted in apigenin concentration-dependent depletion of cellular polyamine levels (Figure 6(b)). These results indicate there was a synergistic effect with the combined treatment of DFMO and apigenin, thus suggesting that apigenin contributes to polyamine catabolism by targeting SSAT. The reason for this is that SSAT is an inducible enzyme, while APAO (acetylpolyamine oxidase) is generally constitutively expressed and rate-limited by the availability of the acetylated substrate (Figure 1).

\subsection{Apigenin Treatment, as well as Treatment with a Combi-} nation of DMFO and Apigenin, Increased Cellular ROS Levels. To investigate whether apigenin augmented ROS induced by overexpression of SSAT in SW620 cells, cells were treated with $2.5 \mathrm{mM}$ DFMO, apigenin at 10,20 , and $40 \mu \mathrm{M}$, or a combination of $2.5 \mathrm{mM}$ DFMO and $40 \mu \mathrm{M}$ apigenin for up to $48 \mathrm{~h}$. ROS level analysis revealed that exposure to $2.5 \mathrm{mM}$ DFMO resulted in a significant increase in cellular ROS $(p<0.01)$. There was a $1-$ to 1.3 -fold increase in the percentage of ROS levels, with the addition of increasing apigenin concentrations, versus control. DFMO combined with $40 \mu \mathrm{M}$ apigenin produced a 1- to 1.5-fold increase in ROS levels compared to control $(p<0.01)$ (Figures 7 and 9).

3.6. Apigenin Treatment Resulted in Apoptotic Cell Death of SW620 Cells and Treatment with DFMO and Apigenin Further Increased Apoptosis. To further validate the effects of apigenin and DFMO on cell apoptosis, SW620 cells were treated with $2.5 \mathrm{mM}$ DFMO, 10, 20, and $40 \mu \mathrm{M}$ apigenin, or combination of $2.5 \mathrm{mM}$ DFMO and $40 \mu \mathrm{M}$ apigenin for $48 \mathrm{~h}$. Treatment led to induction of apoptosis as measured by the flow cytometry. The treatment promoted a concentrationdependent apoptosis, whereas a combination of DFMO and $40 \mu \mathrm{M}$ apigenin had a more evident effect on apoptosis compared to untreated cells (Figures 8 and 9).

\section{Discussion}

The natural flavonoid apigenin has shown antiproliferative activity against a variety of human cancer cells [1-4] and it has also been suggested as an anticancer drug for the treatment of colon cancer since it has been shown to inhibit the proliferation of human colon tumor HCT-116 cells [5].

Polyamine catabolism produces hydrogen peroxide and a reactive aldehyde, which are able to damage DNA and other critical cellular components. The catabolic pathway also depletes intracellular concentrations of spermidine and spermine, which are free radical scavengers (Figure 2). SSAT is a key rate-limiting enzyme in mammalian polyamine catabolism, which can be induced by various stimuli, like natural polyamines, polyamine analogues, hormones and cytokines, drugs, and so on [45-47]. Therefore, an increase in the activity of SSAT may be an initiating signal for the cessation of cell growth and proliferation. Indeed, this is the key enzyme for regulating the response of polyamine for downregulation of growth for the short half-life of this enzyme and its inducibility in response to stimuli. Other polyamine acetyltransferases are present in eukaryotic cells, including acetyltransferase, with specificity for the N8-amino group of spermidine, but the activity of this enzyme dose did not change significantly in a previous in vitro study and seems to be of less importance for the regulation of cell growth [48].

To the best of our knowledge, this is the first study to explore the effect of apigenin on polyamine catabolism by targeting spermidine/spermine-N1-Acetyltransferase and 

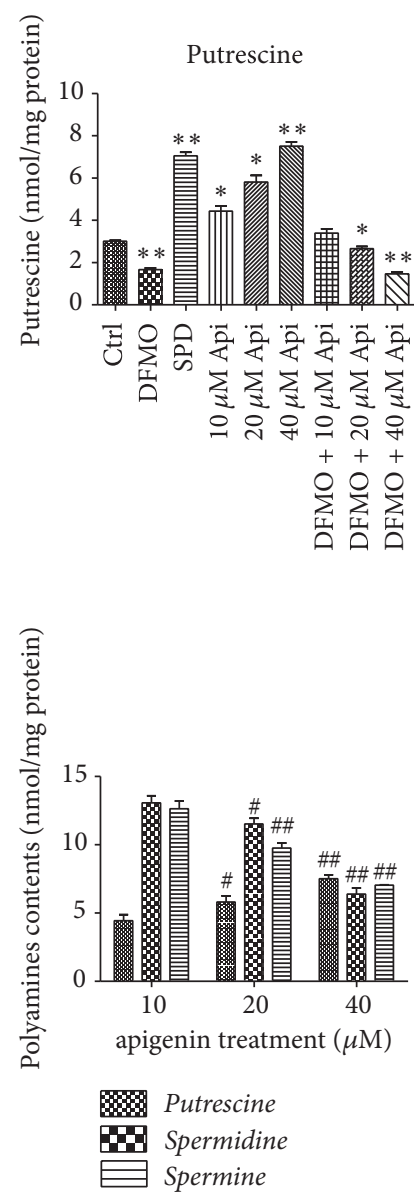
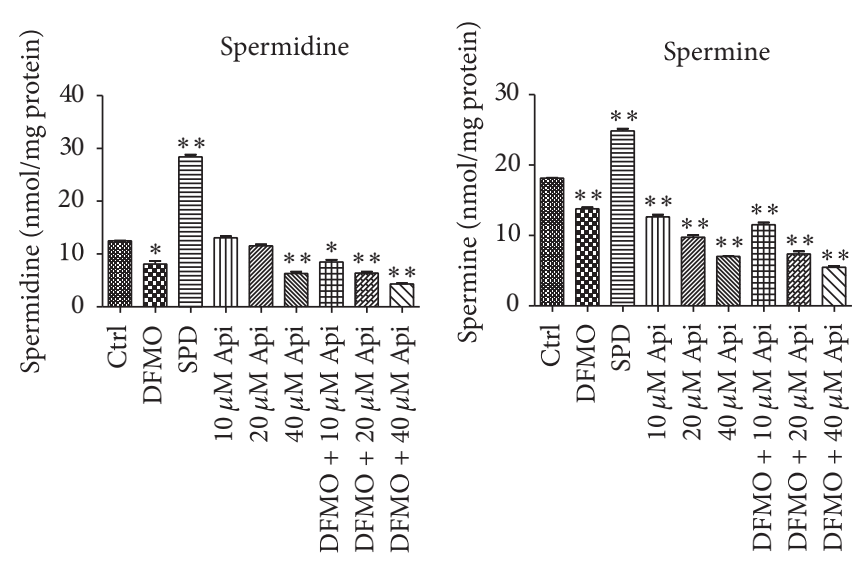

(a)

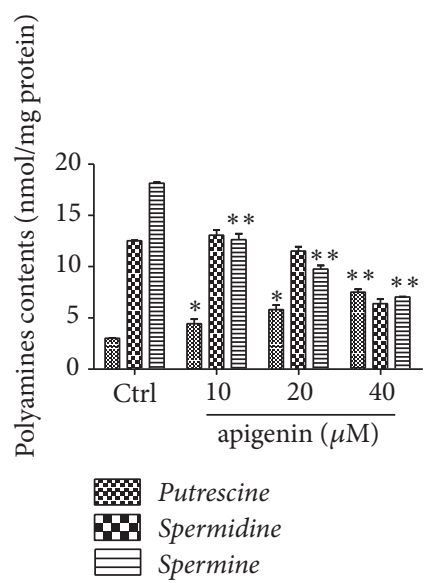

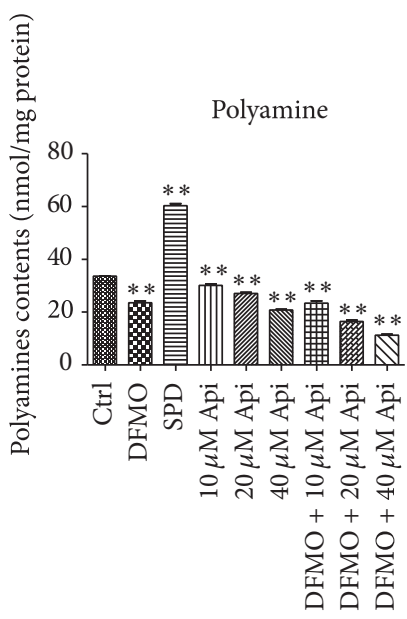

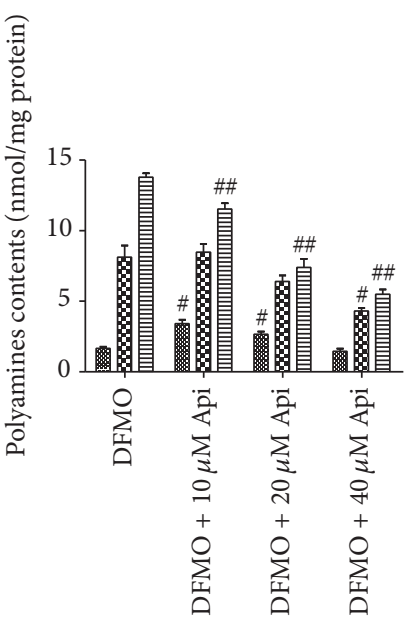

DFMO and combination of DMFO and apigenin

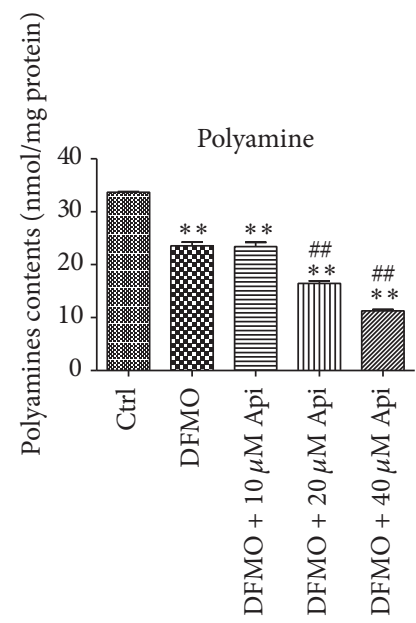

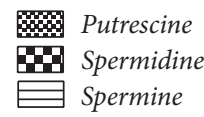

(b)

Figure 6: (a) Analysis of putrescine, spermidine, spermine, and total polyamine contents (nmol/mg protein) in SW620 cells treated with apigenin $(10,20$, and $40 \mu \mathrm{M})$, exogenous-spermidine $(5 \mu \mathrm{M})$, DFMO $(2.5 \mathrm{mM})$, and a combination of DFMO and apigenin (10, 20, and 40 $\mu \mathrm{M})$ for $48 \mathrm{~h}$. Total polyamine contents were decreased by both apigenin and DFMO. Furthermore, the combination of apigenin and DFMO induced an even greater decrease in polyamine levels. ${ }^{*} p<0.05$ and ${ }^{* *} p<0.01$ versus control. (b) Cells exposed to increased concentrations of apigenin demonstrate a concentration-dependent increase in putrescine level and decrease in spermine level with a decrease in total polyamine content. Accordingly, intergroup and intragroup polyamine levels were analyzed. ${ }^{\#} p<0.05$ and ${ }^{\# \#} p<0.01$ compare doses; ${ }^{*} p<0.05$ and ${ }^{* *} p<0.01$ versus control. (c) In order to investigate the effect of a combination of DFMO and apigenin on polyamine levels, increasing concentrations of apigenin were combined with DFMO. Total polyamine content was analyzed by intergroup comparison. ${ }^{\#} p<0.05$ and ${ }^{\# \#} p<0.01$ compare doses; ${ }^{*} p<0.05$ and ${ }^{* *} p<0.01$ versus control.

induction of apoptosis. Data from the present study demonstrates that apigenin treatment for $24 \mathrm{~h}-72 \mathrm{~h}$ influenced the proliferation rate of SW620 cells in a dose -dependent manner (Figure 3). SSAT protein and mRNA levels significantly increased after exposure to apigenin for $48 \mathrm{~h}$ (Figures 4 and 5). The acceleration of polyamine catabolism by apigenin treatment was further supported by HPLC data (Figure 6). Treatment with different concentration of apigenin resulted in an acceleration of cellular polyamine catabolism in a dose dependent manner, which was manifested in the increase of putrescine and decrease of spermine and spermidine levels. Combined treatment with DFMO and apigenin resulted in 


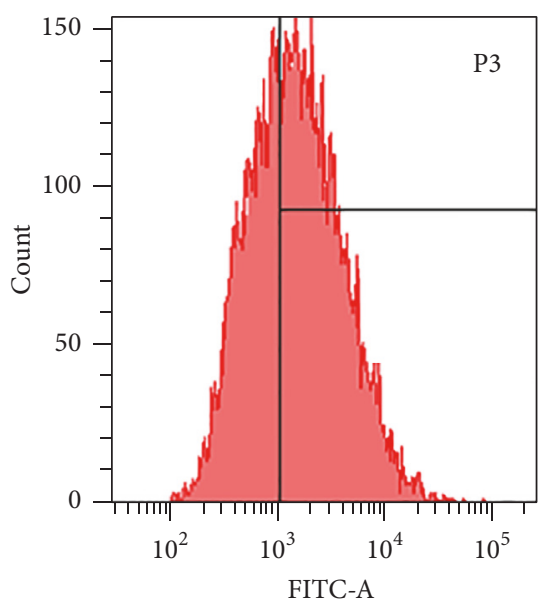

Control

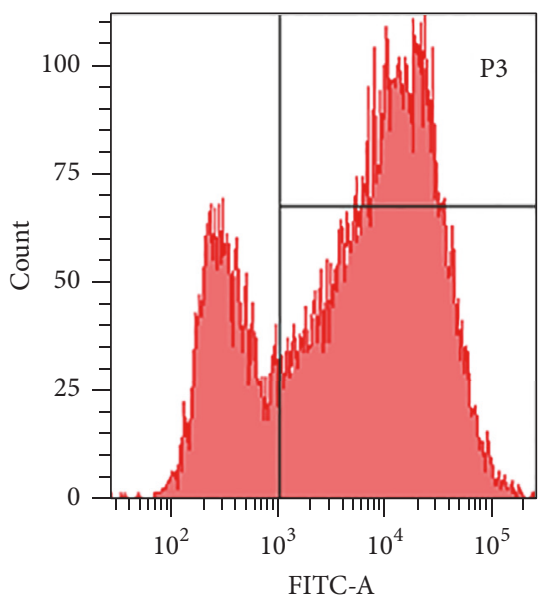

$20 \mu \mathrm{M}$ apigenin
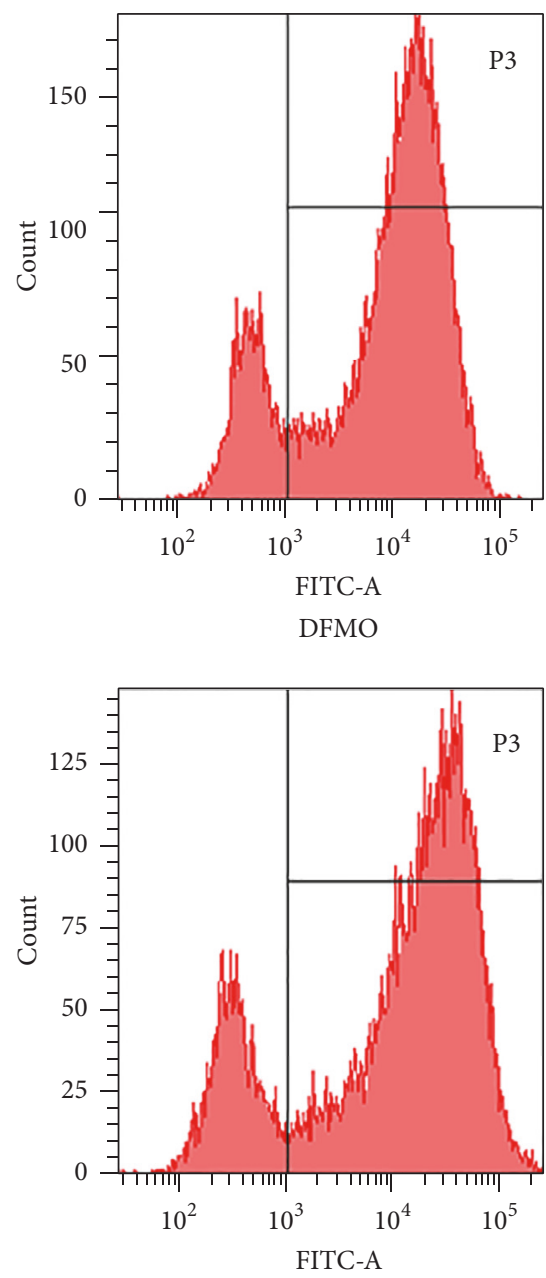

$40 \mu \mathrm{M}$ apigenin

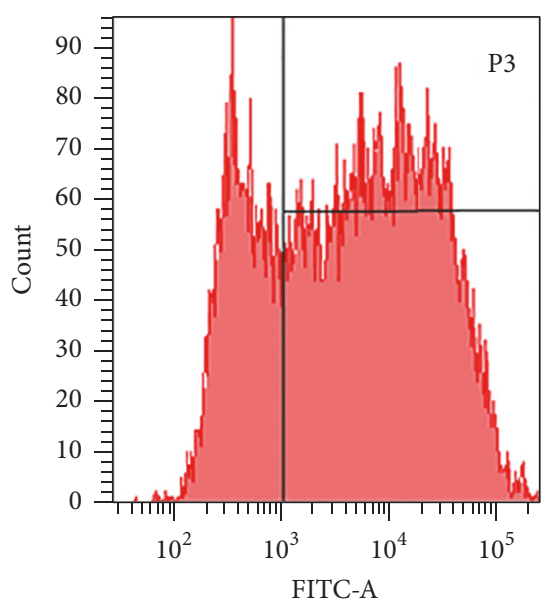

$10 \mu \mathrm{M}$ apigenin

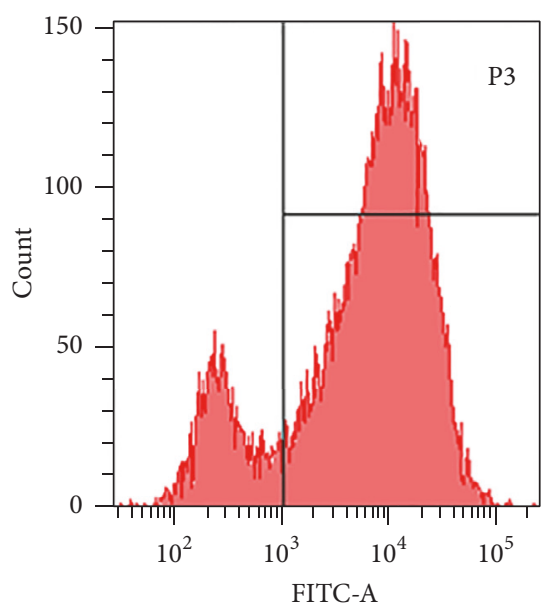

$\mathrm{DFMO}+40 \mu \mathrm{M}$ apigenin

FIGURE 7: Cellular ROS level analysis. ROS levels were significantly increased in SW620 cells treated with apigenin (10, 20, and 40 $\mu$ M), DFMO $(2.5 \mathrm{mM})$, or combination of $5 \mathrm{mM}$ DFMO and $40 \mu \mathrm{M}$ apigenin.

a depletion of cellular polyamine levels. When investigating the mechanisms behind the effect of apigenin treatment on polyamine levels, a great increase in ROS levels was observed in SW620 cells (Figure 7). This suggests strongly that SSAT is responsible for the induction of ROS and that an increase in SSAT is an early indication of potential cellular injury. Subsequent apoptotic analysis further indicated that the apigenin-induced SSAT activity was associated with cell death by apoptosis (Figure 8). Taken together, these results indicate that apigenin may affect the growth of human SW620 cells and decrease the rate of cell proliferation by facilitating SSAT expression to induce polyamine catabolism and increase ROS levels to induce cell apoptosis.

In summary, apigenin treatment induces a rise in the expression of SSAT in human SW620 colon cancer cells. This increase may be an initiating signal for apoptosis and is likely to be destructive to the cell in that it will catabolize polyamine to act as a cellular ROS scavenger. Increased SSAT expression will increase the acetylpolyamine derivatives produced; since these were not detected within the cells they are presumably further metabolized or released into the extracellular medium [49]. Considering the ability of SSAT to reduce the cellular concentrations of the free radical scavenging higher polyamines, as well as producing a reactive aldehyde and $\mathrm{H}_{2} \mathrm{O}_{2}$ that can result in mutagenic DNA damage or chromatin changes, polyamine catabolism could be a promising target for chemoprevention or chemotherapy. The effect of apigenin on polyamine catabolism warrants further investigation.

\section{Conflicts of Interest}

The authors declare that they have no conflicts of interest. 

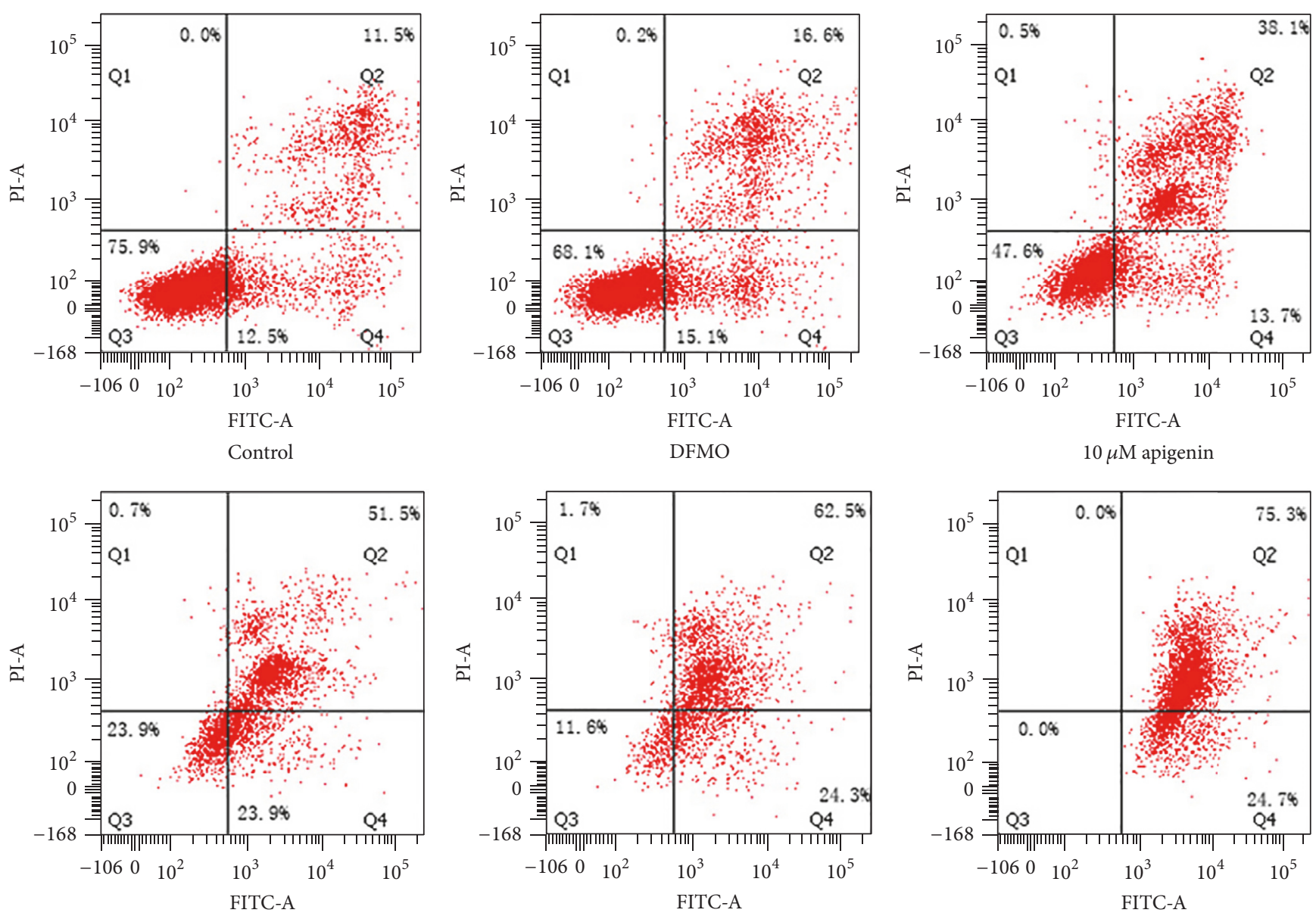

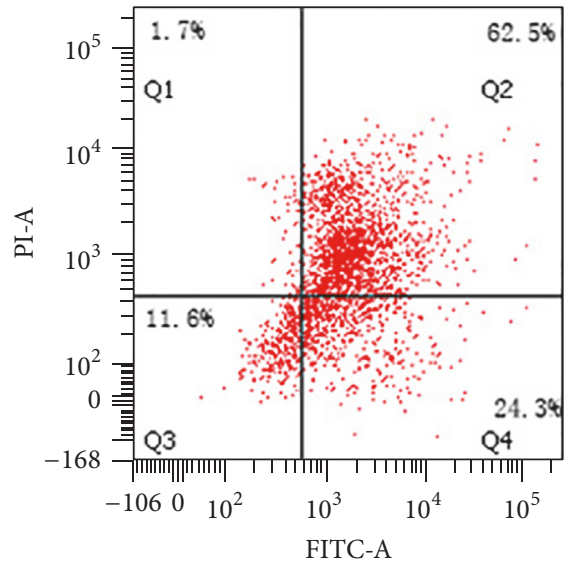

$40 \mu \mathrm{M}$ apigenin

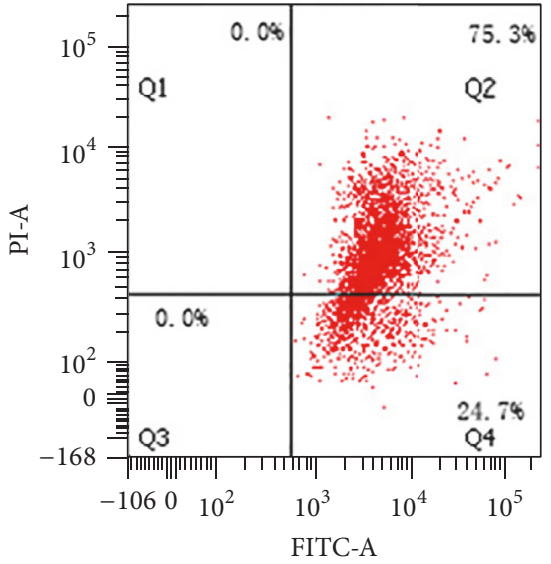

$\mathrm{DFMO}+40 \mu \mathrm{M}$ apigenin

Figure 8: Apoptosis analysis and quantification. Apoptosis was significantly induced in SW620 cells after treatment with apigenin (10, 20, and $40 \mu \mathrm{M})$, DFMO $(5 \mathrm{mM})$, or combination of $5 \mathrm{mM}$ DFMO and $40 \mu \mathrm{M}$ apigenin.
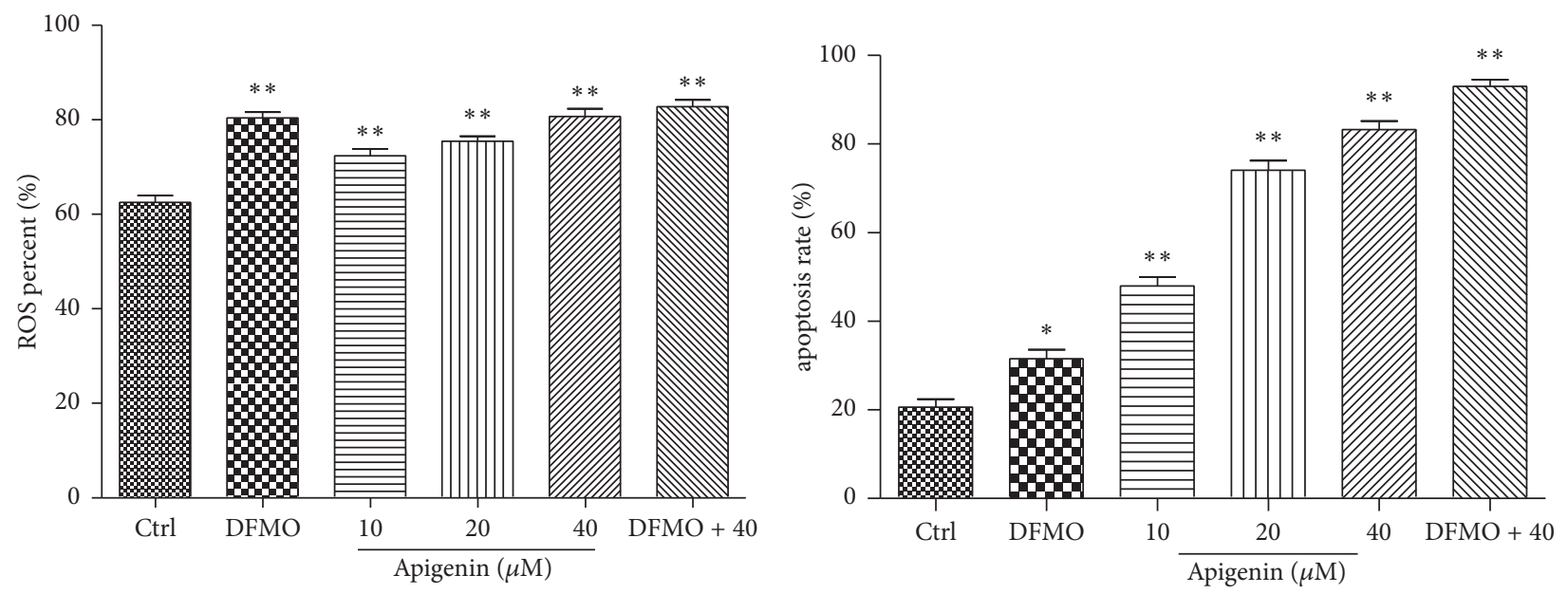

FIGURE 9: Quantification of ROS levels and cell apoptosis. ${ }^{*} p<0.05$ and ${ }^{* *} p<0.01$ versus control. 


\section{References}

[1] S. I. Choi, C. S. Jeong, S. Y. Cho, and Y. S. Lee, "Mechanism of apoptosis induced by apigenin in HepG2 human hepatoma cells: involvement of reactive oxygen species generated by NADPH oxidase," Archives of Pharmacal Research, vol. 30, no. 10, pp. 1328-1335, 2007.

[2] C.-Y. Cheng, C.-C. Hu, H.-J. Yang, M.-C. Lee, and E.-S. Kao, "Inhibitory effects of scutellarein on proliferation of human lung cancer A549 cells through ERK and NF $\kappa$ B mediated by the EGFR pathway," Chinese Journal of Physiology, vol. 57, no. 4, pp. 182-187, 2014.

[3] W. Lim, S. Park, F. W. Bazer, and G. Song, "Apigenin reduces survival of choriocarcinoma cells by inducing apoptosis via the PI3K/AKT and ERK1/2 MAPK pathways," Journal of Cellular Physiology, vol. 231, no. 12, pp. 2690-2699, 2016.

[4] M. A. Hasnat, M. Pervin, J. H. Lim, and B. O. Lim, "Apigenin attenuates melanoma cell migration by inducing anoikis through integrin and focal adhesion kinase inhibition," Molecules, vol. 20, no. 12, pp. 21157-21166, 2015.

[5] H. Pham, M. Chen, H. Takahashi et al., "Apigenin inhibits NNKinduced focal adhesion kinase activation in pancreatic cancer cells," Pancreas, vol. 41, no. 8, pp. 1306-1315, 2012.

[6] R. S. Sulaiman, H. D. Basavarajappa, and T. W. Corson, "Natural product inhibitors of ocular angiogenesis," Experimental Eye Research, vol. 129, pp. 161-171, 2014.

[7] Y. Lee, B. Sung, Y. J. Kang et al., "Apigenin-induced apoptosis is enhanced by inhibition of autophagy formation in HCT116 human colon cancer cells," International Journal of Oncology, vol. 44, no. 5, pp. 1599-1606, 2014.

[8] R. A. Casero and L. J. Marton, "Targeting polyamine metabolism and function in cancer and other hyperproliferative diseases," Nature Reviews Drug Discovery, vol. 6, no. 5, pp. 373-390, 2007.

[9] E. Larqué, M. Sabater-Molina, and S. Zamora, "Biological significance of dietary polyamines," Nutrition, vol. 23, no. 1, pp. 87-95, 2007.

[10] R. A. Casero Jr., B. Frydman, T. M. Stewart, and P. M. Woster, "Significance of targeting polyamine metabolism as an antineoplastic strategy: Unique targets for polyamine analogues," Proceedings of the Western Pharmacology Society, vol. 48, pp. 2430, 2005.

[11] C. Moinard, L. Cynober, and J.-P. de Bandt, "Polyamines: metabolism and implications in human diseases," Clinical Nutrition, vol. 24, no. 2, pp. 184-197, 2005.

[12] N. Seiler and F. Dezeure, "Polyamine transport in mammalian cells," International Journal of Biochemistry, vol. 22, no. 3, pp. 211-218, 1990.

[13] V. Battaglia, C. DeStefano Shields, T. Murray-Stewart, and R. A. Casero Jr., "Polyamine catabolism in carcinogenesis: potential targets for chemotherapy and chemoprevention," Amino Acids, vol. 46, no. 3, pp. 511-519, 2014.

[14] A. Mohammed, N. B. Janakiram, V. Madka et al., "Eflornithine (DFMO) prevents progression of pancreatic cancer by modulating ornithine decarboxylase signaling," Cancer Prevention Research, vol. 7, no. 12, pp. 1198-1209, 2014.

[15] M. R. Burns, G. F. Graminski, R. S. Weeks, Y. Chen, and T. G. O’Brien, "Lipophilic lysine-spermine conjugates are potent polyamine transport inhibitors for use in combination with a polyamine biosynthesis inhibitor," Journal of Medicinal Chemistry, vol. 52, no. 7, pp. 1983-1993, 2009.
[16] A. E. Pegg and R. A. Casero Jr., "Current status of the polyamine research field," in Polyamines, vol. 720 of Methods and Protocols, pp. 3-35, Humana Press, 2011.

[17] K. Igarashi and K. Kashiwagi, "Modulation of cellular function by polyamines," International Journal of Biochemistry and Cell Biology, vol. 42, no. 1, pp. 39-51, 2010.

[18] A. N. Lopatin, E. N. Makhina, and C. G. Nichols, "Potassium channel block by cytoplasmic polyamines as the mechanism of intrinsic rectification," Nature, vol. 372, no. 6504, pp. 366-369, 1994.

[19] K. Williams, "Modulation and block of ion channels: a new biology of polyamines," Cellular Signalling, vol. 9, no. 1, pp. 113, 1997.

[20] H. C. Ha, N. S. Sirisoma, P. Kuppusamy, J. L. Zweier, P. M. Woster, and R. A. Casero Jr., "The natural polyamine spermine functions directly as a free radical scavenger," Proceedings of the National Academy of Sciences of the United States of America, vol. 95, no. 19, pp. 11140-11145, 1998.

[21] H. T. Kurata, L. J. Marton, and C. G. Nichols, "The polyamine binding site in inward rectifier $\mathrm{K}^{+}$channels," Journal of General Physiology, vol. 127, no. 5, pp. 467-480, 2006.

[22] M. Kidd, L. H. Tang, S. W. Schmid et al., "A polyamine pathwaymediated mitogenic mechanism in enterochromaffin-like cells of Mastomys," American Journal of Physiology-Gastrointestinal and Liver Physiology, vol. 275, no. 2, pp. G370-G376, 1998.

[23] T. D. Johnson, "Modulation of channel function by polyamines," Trends in Pharmacological Sciences, vol. 17, no. 1, pp. 22-26, 1996.

[24] N. Seiler, "Thirty years of polyamine-related approaches to cancer therapy. Retrospect and prospect. Part 1. Selective enzyme inhibitors," Current Drug Targets, vol. 4, no. 7, pp. 537-564, 2003.

[25] N. Seiler, "Thirty years of polyamine-related approaches to cancer therapy. Retrospect and prospect. Part 2. Structural analogues and derivatives," Current Drug Targets, vol. 4, no. 7, pp. 565-585, 2003.

[26] T. S. Weiss, G. Bernhardt, A. Buschauer et al., "Polyamine levels of human colorectal adenocarcinomas are correlated with tumor stage and grade," International Journal of Colorectal Disease, vol. 17, no. 6, pp. 381-387, 2002.

[27] F. L. Meyskens and E. W. Gerner, "Development of difluoromethylornithine as a chemoprevention agent for the management of colon cancer," Journal of Cellular Biochemistry, vol. 59, supplement 22, pp. 126-131, 1995.

[28] V. A. Levin, J. H. Uhm, K. A. Jaeckle et al., "Phase III randomized study of postradiotherapy chemotherapy with $\alpha$ difluoromethylornithine-procarbazine, $\mathrm{N}$-(2-chloroethyl)- $\mathrm{N}^{\prime}$ cyclohexyl-N-nitrosurea, vincristine (DFMO-PCV) versus PCV for glioblastoma multiforme," Clinical Cancer Research, vol. 6, no. 10, pp. 3878-3884, 2000.

[29] V. A. Levin, K. R. Hess, A. Choucair et al., "Phase III randomized study of postradiotherapy chemotherapy with combination $\alpha$-difluoromethylornithine-PCV versus PCV for anaplastic gliomas," Clinical Cancer Research, vol. 9, no. 3, pp. 981-990, 2003.

[30] F. L. Meyskens Jr., C. E. McLaren, D. Pelot et al., "Difluoromethylornithine plus sulindac for the prevention of sporadic colorectal adenomas: a randomized placebo-controlled, double-blind trial," Cancer Prevention Research, vol. 1, no. 1, pp. 32-38, 2008.

[31] A. E. Pegg, R. Madhubala, T. Kameji, and R. J. Bergeron, "Control of ornithine decarboxylase activity in $\alpha$-difluoromethylornithine-resistant L1210 cells by polyamines and synthetic 
analogues," Journal of Biological Chemistry, vol. 263, no. 22, pp. 11008-11014, 1988.

[32] D. H. Russell, "Clinical relevance of polyamines as biochemical markers of tumor kinetics," Clinical Chemistry, vol. 23, no. 1, pp. 22-27, 1977.

[33] S. Sarhan, B. Knödgen, and N. Seiler, "Polyamine deprivation, malnutrition and tumor growth," Anticancer Research, vol. 12, no. 2, pp. 457-466, 1991.

[34] N. Seiler, S. Sarhan, C. Grauffel et al., "Endogenous and exogenous polyamines in support of tumor growth," Cancer Research, vol. 50, no. 16, pp. 5077-5083, 1990.

[35] A. Ask, L. Persson, and O. Heby, "Increased survival of L1210 leukemic mice by prevention of the utilization of extracellular polyamines. Studies using a polyamineuptake mutant, antibiotics and a polyamine-deficient diet," Cancer Letters, vol. 66, no. 1, pp. 29-34, 1992.

[36] A. E. Pegg, "Polyamine metabolism and its importance in neoplastic growth and as a target for chemotherapy," Cancer Research, vol. 48, no. 4, pp. 759-774, 1988.

[37] B. Toursarkissian, E. D. Endean, and S. M. Aziz, "Characterization of polyamine transport in rat aortic smooth muscle cells," Journal of Surgical Research, vol. 57, no. 3, pp. 401-407, 1994.

[38] A. E. Pegg, "Spermidine/spermine- $\mathrm{N}^{1}$-acetyltransferase: a key metabolic regulator," American Journal of Physiology -Endocrinology and Metabolism, vol. 294, no. 6, pp. E995-E1010, 2008.

[39] S.-Q. Xie, Y.-H. Zhang, Q. Li et al., "COX-2-independent induction of apoptosis by celecoxib and polyamine naphthalimide conjugate mediated by polyamine depression in colorectal cancer cell lines,' International Journal of Colorectal Disease, vol. 27, no. 7, pp. 861-868, 2012.

[40] R. G. Schipper, L. C. Penning, and A. A. J. Verhofstad, "Involvement of polyamines in apoptosis. Facts and controversies: Effectors or protectors?" Seminars in Cancer Biology, vol. 10, no. 1, pp. 55-68, 2000.

[41] S. Chopra and H. M. Wallace, "Induction of spermidine/ spermine $\mathrm{N}^{1}$-acetyltransferase in human cancer cells in response to increased production of reactive oxygen species," Biochemical Pharmacology, vol. 55, no. 7, pp. 1119-1123, 1998.

[42] R. Schreck, P. Rieber, and P. A. Baeuerle, "Reactive oxygen intermediates as apparently widely used messengers in the activation of the NF-kappa B transcription factor and HIV-1," EMBO Journal, vol. 10, no. 8, p. 2247, 1991.

[43] R. E. Parchment, "The implications of a unified theory of programmed cell death, polyamines, oxyradicals and histogenesis in the embryo," International Journal of Developmental Biology, vol. 37, no. 1, pp. 75-83, 2003.

[44] Y. Wang, W. Devereux, P. M. Woster et al., "Cloning and characterization of a human polyamine oxidase that is inducible by polyamine analogue exposure," Cancer Research, vol. 61, no. 14, pp. 5370-5373, 2001.

[45] I. Matsui, L. Wiegand, and A. E. Pegg, "Properties of spermidine $\mathrm{N}$-acetyltransferase from livers of rats treated with carbon tetrachloride and its role in the conversion of spermidine into putrescine," Journal of Biological Chemistry, vol. 256, no. 5, pp. 2454-2459, 1981.

[46] F. Dai, W. Yu, J. Song, Q. Li, C. Wang, and S. Xie, "Extracellular polyamines-induced proliferation and migration of cancer cells by ODC, SSAT, and Aktl-mediated pathway," Anti-Cancer Drugs, vol. 28, no. 4, pp. 457-464, 2017.

[47] S. Erdogan, O. Doganlar, Z. B. Doganlar et al., "The flavonoid apigenin reduces prostate cancer $\mathrm{CD} 44^{+}$stem cell survival and migration through PI3K/Akt/NF- $\kappa \mathrm{B}$ signaling," Life Sciences, vol. 162, pp. 77-86, 2016.

[48] H. M. Wallace, D. E. Ball, and C. S. Coleman, "Evidence for a cytosolic N8-spermidine acetyltransferase in human colonic carcinoma cells," in Polyamines in the Gastrointestinal Tract, pp. 87-93, Kluwer Academic Publishers, Dordrecht, South Holland, The Netherlands, 1992.

[49] V. G. Brunton, M. H. Grant, and H. M. Wallace, "Mechanisms of spermine toxicity in baby-hamster kidney (BHK) cells: The role of amine oxidases and oxidative stress," Biochemical Journal, vol. 280, no. 1, pp. 193-198, 1991. 


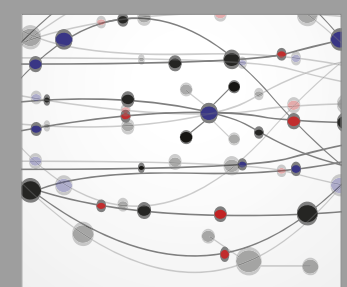

The Scientific World Journal
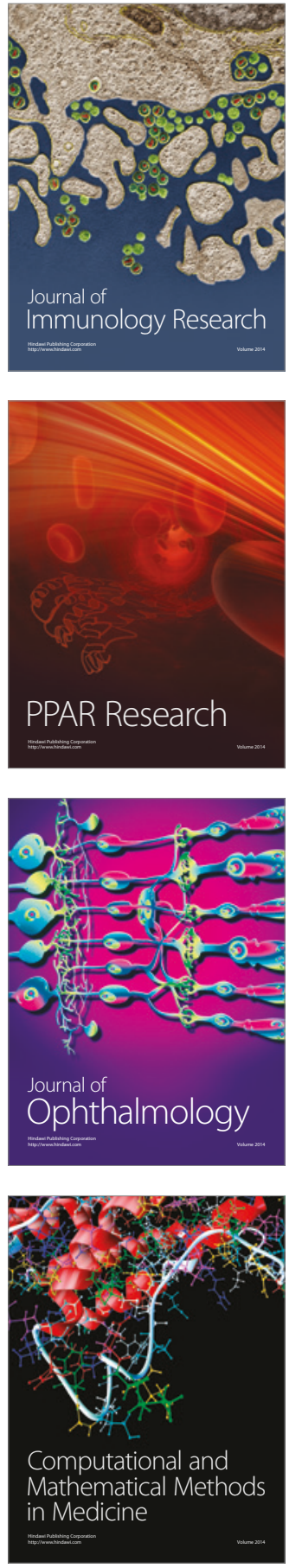

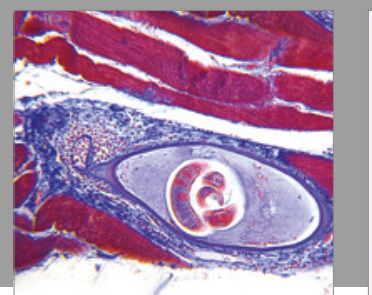

Gastroenterology Research and Practice
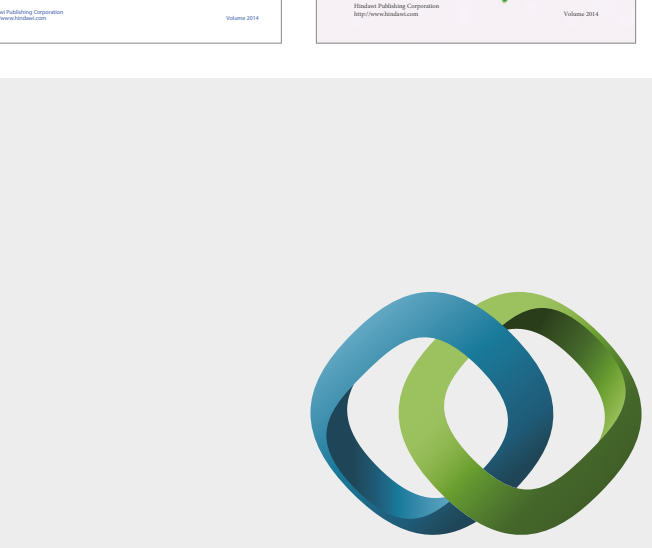

\section{Hindawi}

Submit your manuscripts at

https://www.hindawi.com
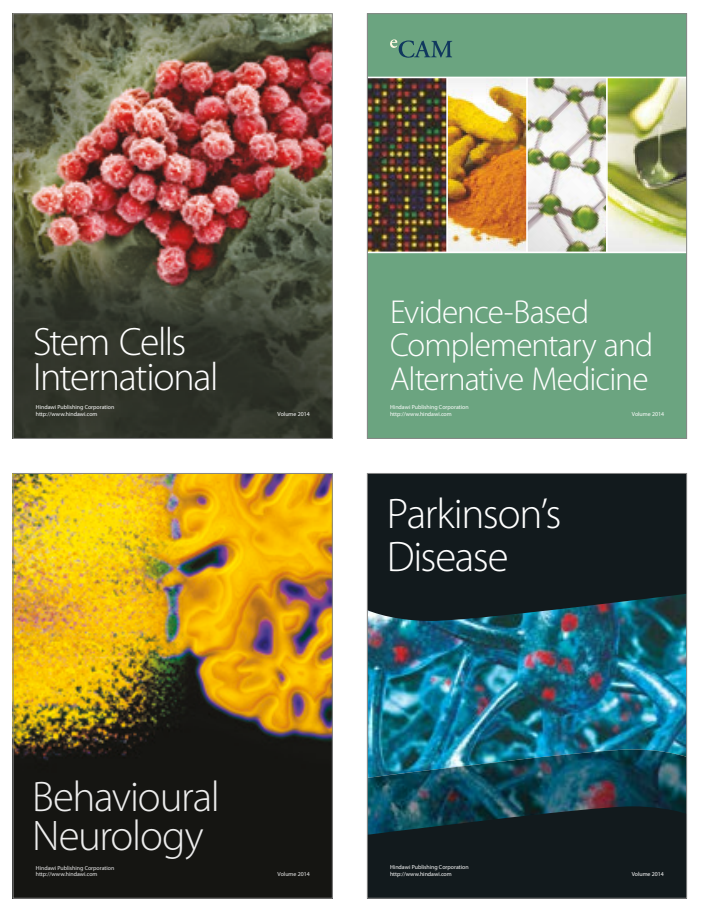
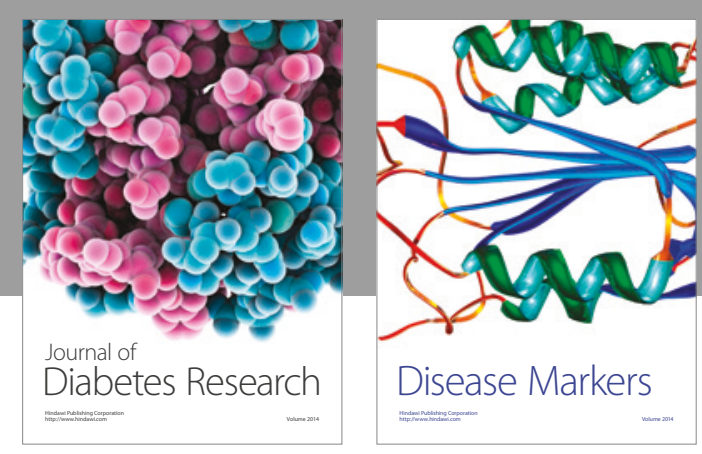

Disease Markers
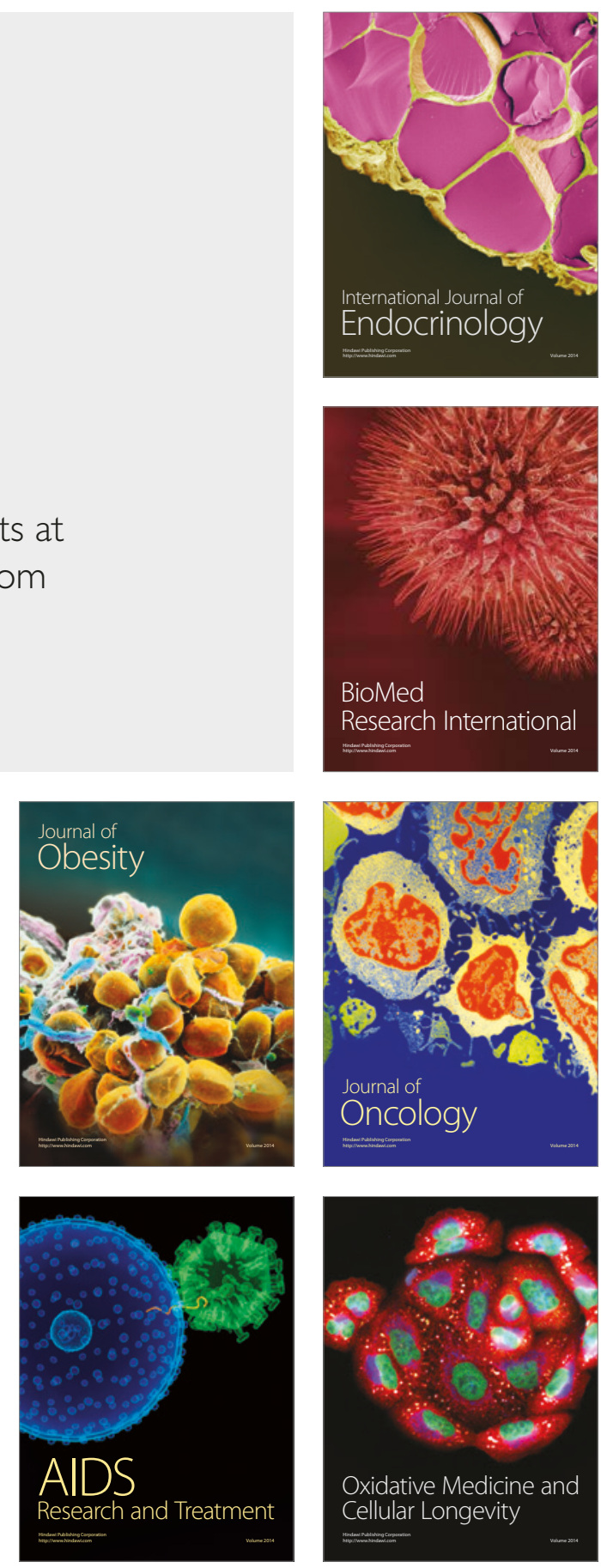